\title{
Penentuan Prioritas Kesejahteraan Keluarga Menggunakan Metode the Extended Promethee II
}

\author{
Masna Wati ${ }^{a, 1, *}$, Ferry Miechel Lubis a,2 dan Andi Tejawati ${ }^{a, 3}$ \\ ${ }^{a}$ Universitas Mulawarman, Jl. Kuaro I, Kampus Sempaja, Samarinda, Kalimantan Timur 75119 \\ Imasnawati@fkti.unmul.ac.id; 2 ferrymiechel@gmail.com; 3 anditejawati117@yahoo.com \\ * corresponding author
}

\section{INFORMASI ARTIKEL \\ Dikirim: 28 Februari 2020 \\ Diulas: 11 Maret 2020 \\ Direvisi: 7 April 2020 \\ Diterbitkan: 27 April 2020}

Kata Kunci:

kemiskinan

kesejahteraan keluarga

bantuan

sistem pendukung keputusan

EXPROM II

Keywords:

Poverty

family welfare

assistance

decision support system

EXPROM II

\section{ABSTRAK}

Indonesia merupakan negara berkembang dimana masalah kemiskinan menjadi salah satu permasalahan yang dihadapi oleh setiap provinsi. Pemerintah terus berupaya untuk mengatasi masalah kemiskinan ini agar mampu menciptakan kondisi masyarakat yang sejahtera. Upaya yang dilakukan pemerintah saat ini dengan memberikan program bantuan untuk pengentasan kemiskinan. Oleh karena itu, perlu dibangun sebuah sistem pendukung keputusan yang berguna membantu pemerintah untuk mengambil sebuah keputusan. Sistem pendukung keputusan ini menerapkan metode EXPROM II (the Extended Promethee II) dan menggunakan bobot kriteria objektif dengan kriteria yang digunakan sebanyak 15 kriteria berdasarkan data SUSENAS Badan Pusat Statistik Provinsi Kalimantan Timur. Penelitian ini menghasilkan sebuah sistem pendukung keputusan yang mampu memberikan urutan prioritas tingkat kesejahteraan keluarga sehingga dapat menjadi pertimbangan atau rujukan oleh pemerintah daerah atau dinas terkait dalam pemberian bantuan kepada masyarakat.

\section{ABSTRACT}

Indonesia is a developing country in which poverty is one of the problems faced by each province. The government continues to strive to overcome this problem of poverty to be able to create conditions for a prosperous society. The government's efforts to poverty alleviation are by providing some assistance programs. Therefore, it is necessary to build a decision support system that is useful to help the government to make a decision. This decision support system applies the EXPROM II (The Extended Promethee II) method with the weight of objective criteria. There are 15 criteria used based on SUSENAS data from the Statistics Indonesia of East Kalimantan Province. This research resulted in a decision support system that can give priority order of the level of family welfare so that it can be considered or referred by the local government or related agencies in distributing assistance to the society.

This is an open access article under the CC-BY-SA license.

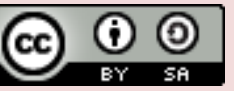

\section{Pendahuluan}

Kemiskinan merupakan masalah kemanusiaan yang mendunia dan sampai saat ini menjadi isu utama di berbagai dunia negara-negara terbelakang maupun negara-negara berkembang [1]-[3]. Negara-negara maju pun tak lepas dari masalah ini, penurunan tingkat kemiskinan dan peningkatan kesejahteraan masyarakat juga menjadi hal prioritas dalam pembangunan dan pertumbuhan ekonomi. Indonesia merupakan negara berkembang dimana masalah kemiskinan menjadi salah satu permasalahan yang dihadapi oleh setiap provinsi.

Kota Samarinda yang menjadi ibukota Provinsi Kalimantan Timur juga menhadapi masalah kemiskinan. Menurut Badan Pusat Statistik (BPS) Kota Samarinda (2018) jumlah penduduk miskin dari tahun 2011 -2017 cenderung naik atau dalam trend naik. Saat ini jumlahnya mencapai 4,77 \% [1], [4], [5]. Pemerintah terus berupaya untuk menekan angka kemiskinan melalui berbagai program seperti Program Keluarga Harapan (PKH), Beras Sejahtera, bantuan hunian sederhana (Rutihalu), Santunan Warga Tidak Mampu (SWTM) [2], [6], [7]. Pengentasan kemiskinan tentunya diharapkan mampu menciptakan kesejahteraan masyarakat, yang mana peningkatan kesejahteraan masyarakat mencerminkan upaya pembangunan berjalan dengan baik.

Oleh karena itu, pemerintah daerah selalu berupaya untuk memantau dan mengidentifikasi warga masyarakat berdasarkan kesejahteraan keluarga. Hal ini dapat menjadi rujukan pemerintah daerah dalam 
pengambilan keputusan program-program bantuan sosial bisa tepat sasaran. Dalam proses tersebut diperlukan sebuah alat bantu yang tepat, salah satunya suatu Sistem Pendukung Keputusan (SPK) penyeleksian penerima bantuan untuk mencegah terjadinya penyaluran bantuan yang tidak tepat sasaran[1], [8][9].

Berdasarkan uraian tersebut maka perlu dilakukan penelitian mengenai kesejahteraan masyarakat dengan melakukan penentuan urutan prioritas tingkat kesejahteraan tiap keluarga. Dalam penelitian ini menggunakan salah satu metode dari Multi Criteria Decison Making (MCDM) yaitu metode the Extended Promethee II (EXPROM II) dalam penentuan urutan prioritas dari kesejahteraan keluarga karena dengan metode ini dapat mengolah data dengan membandingkan kriteria-kriteria antar alternatif yang ada dan membandingkan antar alternatif untuk setiap alternatif. Aplikasi yang dibangun bertujuan untuk mempermudah pemerintah daerah dalam menentukan urutan prioritas tingkat kesejahteraan keluarga berdasarkan hasil output sistem.

\section{Metode}

\section{A. Kesejahteraan Keluarga}

Kesejahteraan adalah suatu tata kehidupan dan penghidupan sosial,material, maupun spiritual yang diliputi rasa keselamatan, kesusilaan dan ketentraman lahir batin yang memungkinkan setiap warga Negara untuk mengadakan usaha-usaha pemenuhan kebutuhan jasmani, rohani dan sosial yang sebaik-baiknya bagi diri, rumah tangga serta masyarakat [10]. Menurut Badan Pusat Statistik (BPS), untuk mengukur tingkat kesejahteraan dapat dilihat dari 7 indikator yang ada, antara lain: Kependudukan, Pendidikan, Kesehatan, Fertilitas dan Keluarga Berencana, Pola Konsumsi, Ketenagakerjaan, dan Perumahan [6], [11].

Kriteria yang digunakan dalam penentuan tingkat kesejahteraan keluarga berdasarkan Survei Sosial Ekonomi Nasional (SUSENAS) BPS, meliputi [7], [12]:

1. Pengeluaran Per Kapita/bulan;

2. Pekerjaan kepala rumah tangga;

3. Kepemilikan asuransi kesehatan;

4. Rawat inap dalam 1 tahun terakhir;

5. Tidak dapat makan yang sehat dan bergizi;

6. Status tempat tinggal;

7. Luas lantai tempat tinggal;

8. Bahan utama atap tempat tinggal;

9. Bahan utama dinding tempat tinggal;

10. Bahan utama lantai tempat tinggal;

11. Sumber air utama memasak;

12. Ketersediaan fasilitas MCK;

13. Ketersediaan listrik;

14. Bahan bakar utama memasak;

15. Kepemilikan harta mobil.

\section{B. Bobot Objektif Kriteria}

Dalam masalah keputusan multi-kriteria, kriteria dan sub kriterianya harus diketahui bobotnya terlebih dahulu. Bobot ini menggambarkan tingkat kepentingan kriteria dalam pengambilan keputusan oleh pengambil keputusan [13]. Penentuan bobot ini dengan menggali informasi dari data sebelumnya untuk mengetahui pola penentuan sejahtera atau tidak sejahteranya keluarga. Untuk penentuan bobot kriteria dan sub kriteria menggunakan bobot objektif melalui metode Entropy dan nilai information gain. Penentuan bobot sub kriteria dengan mencari nilai Entropy untuk setiap kriteria yang ada menggunakan persamaan (1) [12], [14]-[17].

$\operatorname{Entropy}(S)=\sum_{i=1}^{n}-p i * \log _{2} p i$

dimana $n$ adalah jumlah partisi $S$ dan $p i$ adalah proporsi pada kategori.

Untuk menentukan nilai bobot dari kriteria yaitu dengan mencari nilai information gain untuk setiap sub kriteria. Nilai informarion gain dihitung dengan persamaan (2).

$$
\operatorname{Gain}(A)=\operatorname{Entropy}(S)-\sum_{i=1}^{n} \frac{|S i|}{|S|} * \operatorname{Entropy}\left(S_{i}\right)
$$

Dalam persamaan (2), $A$ adalah atribut untuk kumpulan sampel $S, n$ adalah jumlah partisi atribut $A,|S i|$ adalah hitungan kasus di partisi $i$, dan $|S|$ adalah jumlah kasus.

\section{Metode The Extended Promethee II}

The Extended Promethee II (EXPROM II) yang dikembangkan oleh Diakoulaki dan Koumoutsosa adalah versi modifikasi Promethee II yaitu perbandingan deviasi atau jarak antar alternatif berpasangan untuk setiap kriteria. Dalam metode ini, nilai relatif dari salah satu alternatif didefinisikan oleh dua indeks 
preferensi. Pertama adalah indeks preferensi yang lemah berdasarkan agregat atau selisih kriteria, sebagaimana ditemtukan dalam Promethee II. Kedua adalah indeks preferensi yang kuat berdasarkan pada gagasan dari solusi ideal dan anti-ideal. Nilai-nilai ideal dan anti-ideal yang langsung dari matriks keputusan dan mereka mencerminkan batas ekstrim untuk kriteria tertentu [18].

Sebuah indeks preferensi total dihitung dengan menambahkan nilai indeks preferensi yang lemah dan kuat yang memberikan ukuran yang akurat dari preferensi satu alternatif dengan alternatif yang lain untuk semua kriteria yang ada. Perhitungan net flow atau aliran bersih sebuah alternatif ditentukan berdasarkan penjumlahan leaving dan entering flow. EXPROM II menghasilkan perangkingan alternatif berdasarkan nilai net flow setiap alternatif sehingga memberikan alternatif terbaik dengan net flow tertinggi. Berikut adalah langkah dari metode EXPROM II [18]-[21] :

1. Membuat matriks keputusan

Matriks keputusan adalah matriks yang terdiri dari nilai alternatif $i$ untuk setiap kriteria $j$.

2. Normalisasi matriks keputusan

Untuk jenis kriteria benefit menggunakan persamaan (3-4).

$$
r_{i j}=\frac{\left[x_{i j}-\min \left(x_{i j}\right)\right]}{\left[\max \left(x_{i j}\right)-\min \left(x_{i j}\right)\right]}, \quad(i=1,2, \ldots, m ; j=1,2, \ldots, n)
$$

Untuk jenis kriteria cost menggunakan persamaan berikut:

$$
r_{i j}=\frac{\left[\max \left(x_{i j}\right)-x_{i j}\right]}{\left[\max \left(x_{i j}\right)-\min \left(x_{i j}\right)\right]},(i=1,2, \ldots, m ; j=1,2, \ldots, n)
$$

dimana $r_{i j}=$ matriks ternormalisasi, $i=$ alternatif, $j=$ kriteria

3. Penentuan Fungsi Preferensi $P_{j}\left(i, i^{\prime}\right)$

Ada enam jenis fungsi preferensi yang utama, yaitu kriteria biasa, kriteria bentuk $\mathrm{U}$, kriteria bentuk $\mathrm{V}$, kriteria tingkat, kriteria pengabaian bentuk V dan kriteria Gaussian. Bentuk yang paling sederhana dari fungsi preferensi (kriteria biasa) diterapkan disini. Persamaan Fungsi Preferensi $P_{j}\left(i, i^{\prime}\right)$ diberikan pada persamaan (5).

$$
P_{i j}\left(i, i^{\prime}\right)=\left\{\begin{array}{c}
0, \text { if } r_{i j} \leq r_{i^{\prime} j} \\
\left(r_{i j}-r_{i^{\prime} j}\right), \text { if } r_{i j}>r i^{\prime} j
\end{array}\right.
$$

dimana $P_{i j}=$ Fungsi Preferensi, $i=$ alternatif, $i^{\prime}=$ alternatif yang akan dipasangkan

4. Menghitung nilai Weak Preference (WP)

Perhitungan indeks preferensi yang lemah dengan mempertimbangkan kriteria dengan nilai bobot yang berbeda-beda untuk setiap kriteria menggunakan persamaan (6).

$$
W P\left(i, i^{\prime}\right)=\left[\sum_{j=1}^{n} W_{j} x P_{j}\left(i, i^{\prime}\right)\right] / \sum_{j=1}^{n} W_{j}
$$

dimana $W P=$ Weak Preference, $n=$ jumlah kriteria, $W_{j}=$ bobot kriteria $j$

5. Menghitung nilai $\operatorname{SPj}\left(i, i^{\prime}\right)$

Menentukan fungsi preferensi yang kuat $\operatorname{SPj}\left(i, i^{\prime}\right)$. Fungsi preferensi yang kuat berdasarkan perbandingan nilai-nilai perbedaan (dmj) dengan rentang nilai seperti yang didefinisikan oleh evaluasi dari seluruh rangkaian alternatif untuk kriteria pada persamaan (7).

$$
S P_{j}\left(i, i^{\prime}\right)=\left[\max \left(0, d_{j}-L_{j}\right)\right] /\left[d m_{j}-L_{j}\right]
$$

dimana: $S P_{j}=$ Strict Preference kriteria $j, d_{j}=\mathrm{ij}$-ri' $\mathrm{j}, d m_{j}=1, L_{j}=0$

6. Menghitung Nilai Strict Preference (SP)

Perhitungan indeks preferensi yang kuat menggunakan persamaan (8).

$$
S P\left(i, i^{\prime}\right)=\left[\sum_{j=1}^{n} W_{j} x S P_{j}\left(i, i^{\prime}\right)\right] / \sum_{j=1}^{n} W_{j}
$$

dimana $: S P=$ Strict Preference, $n=$ jumlah kriteria, $W_{j}=$ bobot kriteria $j$

7. Menghitung nilai Total Preference $T P\left(i, i^{\prime}\right)$

Perhitungan total nilai indeks preferensi atau Total Preference $T P\left(i, i^{\prime}\right)$ melalui persamaan (9).

$$
T P\left(i, i^{\prime}\right)=\min \left[1, W P\left(i, i^{\prime}\right)+S P\left(i, i^{\prime}\right)\right]
$$


8. Menghitung nilai Entering dan Leaving Flow

Perhitungan aliran yang keluar dan masuk menggunakan persamaan (10) dan (11).

Arah keluar positif untuk alternatif:

$$
\varphi^{+}(i)=\frac{1}{m-1} \sum_{i^{\prime}=1}^{n} T P\left(i, i^{\prime}\right)(i \neq 1)
$$

Arah masuk negatif untuk alternatif:

$$
\varphi^{-}(i)=\frac{1}{m-1} \sum_{i^{\prime}=1}^{m} T P\left(i, i^{\prime}\right)(i \neq 1)
$$

dimana: $i=$ alternatif, $i^{\prime}=$ alternatif yang dipasangkan, $m=$ jumlah alternatif, $n=$ jumlah kriteria

Aliran keluar mengungkapkan seberapa banyak alternatif mendominasi alternatif lainnya, sedangkan untuk aliran yang masuk menunjukan berapa banyak alternatif didominasi oleh alternatif lain.

9. Menghitung Net flow

Nilai aliran perangkingan atau Net flow $\varphi$ (i) untuk setiap alternatif diperoleh dari persamaan (12).

$$
\varphi(i)=\varphi^{+}(i)-\varphi^{-}(i)
$$

10. Perangkingan alterantif berdasarkan nilai net flow tertinggi.

Penentuan peringkat semua alternatif yang dipertimbangkan tergantung pada nilai-nilai dari net flow. Semakin tinggi nilai dari net flow, maka semakin baik pula alternatifnya. Dengan demikian, alternatif terbaik adalah alternatif yang memiliki nilai net flow tertinggi.

\section{Evaluasi}

Dalam mengukur kinerja dari setiap model yang sudah dihasilkan maka perlu menggunakan sebuah metode. Confusion Matrix adalah suatu metode yang digunakan untuk melakukan perhitungan akurasi dalam pembandingkan data nyata dan hasil dari suatu metode. Model dari Confusion Matrix disajikan pada Tabel 1 [14], [22]-[25].

Tabel 1. Model Confusion Matrix

\begin{tabular}{lll}
\hline \multirow{2}{*}{ Data Uji } & \multicolumn{2}{c}{ Data Aktual } \\
\cline { 2 - 3 } & \multicolumn{1}{c}{ True } & \multicolumn{1}{c}{ False } \\
\hline True & True Positive (TP) & False Positive (FP) \\
\hline False & False Negative (FN) & True Negative (TN) \\
\hline
\end{tabular}

dimana:

True Postitive (TP) : jumlah data positif yang dilabeli dengan benar oleh metode

True Negative (TN) : jumlah data negatif yang dilabeli benar oleh metode

False Negative (FN) : jumlah data negatif tetapi dilabeli salah oleh metode

False Positive (FP) : jumlah data positif namun labeli salah oleh metode

Dari confusion matrix, dapat tingkat akurasi menggunakan persamaan (13).

$$
\text { Akurasi }=\frac{T P+T N}{T P+T N+F P+F N} * 100 \%
$$

\section{Hasil dan Pembahasan}

\section{A. Implementasi Metode EXPROM II}

Data set alternatif yang digunakan sebanyak 220 data yang diambil dari data survei SUSENAS 2018 Badan Pusat Statistik Provinsi Kalimantan Timur di Kota Samarinda. Dari 220 data tersebut sebanyak 199 keluarga tergolong dalam keluarga sejahtera dan keluarga tidak sejahtera sebanyak 21 keluarga. Selanjutnya, terdapat 15 kriteria yang digunakan dalam penentuan tingkat kesejahteraan keluarga, dimana masing masing kriteria dan sub kriteria memiliki bobot yang menunjukan tingkat kepentingan dalam proses pengambilan keputusan. Dalam penelitian ini penentuan bobot menggunakan bobot obyektif.

Penentuan bobot obyektif kriteria dan sub kriteria menggunakan metode Entropy. Untuk bobot kriteria diperoleh dari nilai Information Gain dan untuk bobot sub kriteria menggunakan nilai Entropy. Untuk menghitung nilai bobot kriteria dan sub kriteria menggunakan persamaan (1) dan (2), disajikan pada Tabel 2. 
Tabel 2. Bobot Sub Kriteria

\begin{tabular}{|c|c|c|c|c|}
\hline Kriteria & Kode & Bobot Kriteria & Sub Kriteria & Bobot Sub Kriteria \\
\hline \multirow[t]{3}{*}{ Pengeluaran per kapita/bulan } & PP & 0,199 & Rendah & 0,310 \\
\hline & & & Normal & 0,226 \\
\hline & & & Tinggi & 0,070 \\
\hline \multirow{5}{*}{ Pekerjaan krt } & PJK & 0,028 & Berusaha sendiri & 0,451 \\
\hline & & & Usaha dibantu buruh tidak tetap & 0,764 \\
\hline & & & Usaha dibantu buruh tetap & 0,469 \\
\hline & & & Buruh/Karyawan/Pegawai & 0,303 \\
\hline & & & Pekerja bebas & 0,991 \\
\hline \multirow[t]{6}{*}{ Kepemilikan asuransi } & ASR & 0,252 & Tidak Punya & 0 \\
\hline & & & BPJS PBI & 0,323 \\
\hline & & & BPJS NON PBI & 0,051 \\
\hline & & & Jamkesda & 0 \\
\hline & & & Asuransi Swasta & 0 \\
\hline & & & Asuransi Perusahaan/Kantor & 0 \\
\hline \multirow{2}{*}{$\begin{array}{l}\text { Pernah rawat inap dalam } 1 \\
\text { tahun terakhir }\end{array}$} & SKT & 0,004 & $\mathrm{Ya}$ & 0 \\
\hline & & & Tidak & 0,467 \\
\hline \multirow{2}{*}{$\begin{array}{l}\text { Pernah tidak dapat makan yang } \\
\text { sehat dan bergizi }\end{array}$} & MKN & 0,066 & $\mathrm{Ya}$ & 0,722 \\
\hline & & & Tidak & 0,335 \\
\hline \multirow[t]{4}{*}{ Status tempat tinggal } & RMH & 0,016 & Milik Sendiri & 0,365 \\
\hline & & & Kontrak/Sewa & 0,845 \\
\hline & & & Bebas Sewa & 0,529 \\
\hline & & & Rumah Dinas & 0 \\
\hline \multirow[t]{3}{*}{ Luas lantai tempat tinggal } & LLT & 0,055 & $>100 \mathrm{~m} 2$ Luas & 0,199 \\
\hline & & & $>=50 \mathrm{~m} 2$ Cukup & 0,374 \\
\hline & & & $<50 \mathrm{~m} 2$ Sempit & 0,983 \\
\hline \multirow{5}{*}{$\begin{array}{l}\text { Bahan utama atap tempat } \\
\text { tinggal }\end{array}$} & ATP & 0,026 & Beton & 0 \\
\hline & & & Genteng & 0,179 \\
\hline & & & Asbes & 0 \\
\hline & & & Seng & 0,495 \\
\hline & & & Kayu/Sirap & 0,985 \\
\hline \multirow{2}{*}{$\begin{array}{l}\text { Bahan utama dinding tempat } \\
\text { tinggal }\end{array}$} & DND & 0,107 & Tembok & 0 \\
\hline & & & Kayu/Papan & 0,861 \\
\hline \multirow{4}{*}{$\begin{array}{l}\text { Bahan utama lantai tempat } \\
\text { tinggal }\end{array}$} & BLT & 0,097 & Keramik & 0 \\
\hline & & & Ubin/Tegel & 0 \\
\hline & & & Kayu/Papan & 0,837 \\
\hline & & & Semen/Bata Merah & 0,773 \\
\hline \multirow[t]{3}{*}{ Sumber air utama mck } & AIR & 0,015 & Ledeng & 0,391 \\
\hline & & & Sumur Bor & 0,592 \\
\hline & & & Air Permukaan & 0,946 \\
\hline \multirow[t]{2}{*}{ Ketersediaan fasilitas mck } & MCK & 0,005 & MCK Umum & 1 \\
\hline & & & Ada & 0,442 \\
\hline \multirow[t]{3}{*}{ Ketersediaan listrik } & PLN & 0,062 & Non Listrik/Listrik <900 W & 0,592 \\
\hline & & & Listrik $900 \mathrm{~W}$ & 0,485 \\
\hline & & & Listrik $=>1300 \mathrm{~W}$ & 0,196 \\
\hline \multirow[t]{6}{*}{ Bahan bakar utama memasak } & BBM & 0,041 & Kayu Bakar & 0 \\
\hline & & & Minyak Tanah & 0 \\
\hline & & & Elpiji $3 \mathrm{KG}$ & 0,555 \\
\hline & & & Elpiji 5,5 KG & 0 \\
\hline & & & Elpiji $12 \mathrm{KG}$ & 0 \\
\hline & & & Listrik & 0 \\
\hline \multirow[t]{2}{*}{ Kepemilikan harta mobil } & MBL & 0,028 & Tidak Punya & 0,594 \\
\hline & & & Punya & 0,096 \\
\hline
\end{tabular}

Dalam metode EXPROM II untuk nilai bobot kriteria harus dilakukan normalisasi terlebih dahulu. Selanjutnya, langkah metode EXPROM II untuk menentukan tingkat kesejahteraan keluarga berikut:

1) Membuat matriks keputusan dan mengubah nilai sub kriteria menjadi bobot masing-masing sub kriteria setiap alternatif berdasarkan Tabel 2 sehingga diperoleh matriks keputusan yang disajikan pada Tabel 3.

Tabel 3. Matriks Keputusan

\begin{tabular}{lrrrrc}
\hline \multirow{2}{*}{ Alternatif } & \multicolumn{5}{c}{ Kriteria } \\
\cline { 2 - 6 } & PP & PKJ & ASR & $\ldots$ & MBL \\
\hline Keluarga 1 & 0,07 & 0,451 & 0,051 & $\ldots$ & 0,594 \\
\hline Keluarga 2 & 0,07 & 0,451 & 0,051 & $\ldots$ & 0,594 \\
\hline
\end{tabular}




\begin{tabular}{llllll}
\hline Keluarga 3 & 0,07 & 0,451 & 0,051 & $\ldots$ & 0,594 \\
\hline$:$ & $:$ & $:$ & $:$ & $\ldots$ & $:$ \\
\hline Keluarga 220 & 0,226 & 0,303 & 0,051 & $\ldots$ & 0,096 \\
\hline
\end{tabular}

2) Melakukan normalisasi matriks keputusan mnggunakan persamaan (3) untuk tipe kriteria benefit dan persamaan (4) untuk tipe kriteria cost. Hasil dari normalisasi matriks keputusan disajikan pada Tabel 4.

3) Menentukan nilai preferensi $P_{j}$ dari Tabel 4 menggunakan persamaan (5) dimana membandingkan antar alternatif yang ada. Lalu menentukan nilai weak preference (WP) menggunakan persamaan (6) berdasarkan bobot kriteria pada Tabel 2. Hasil dari matriks nilai WP disajikan pada Tabel 5.

Tabel 4. Matriks Normalisasi

\begin{tabular}{lccccc}
\hline \multirow{2}{*}{ Alternatif } & \multicolumn{5}{c}{ Kriteria } \\
\cline { 2 - 6 } & PP & PKJ & ASR & $\ldots$ & MBL \\
\hline Keluarga 1 & 0 & 0,215 & 0,157 & $\ldots$ & 1 \\
\hline Keluarga 2 & 0 & 0,215 & 0,157 & $\ldots$ & 1 \\
\hline Keluarga 3 & 0 & 0,215 & 0,157 & $\ldots$ & 1 \\
\hline$:$ & $:$ & $:$ & $:$ & $:$ & $:$ \\
\hline Keluarga 220 & 0,65 & 0 & 0,157 & $\ldots$ & 0 \\
\hline
\end{tabular}

Tabel 5. Matriks Nilai Weak Prefrence (WP)

\begin{tabular}{llcccccc}
\hline \multirow{2}{*}{ Alternatif } & \multicolumn{7}{c}{ Kriteria } \\
\cline { 2 - 8 } K1 & K2 & 0 & 0 & 0 & $\ldots$ & 0 & 0,258 \\
\hline K1 & K3 & 0 & 0 & 0 & $\ldots$ & 0 & 0,06 \\
\hline K1 & K4 & 0 & 0 & 0 & $\ldots$ & 0,028 & 0,335 \\
\hline$:$ & $:$ & $:$ & $:$ & $:$ & $:$ & $:$ & $:$ \\
\hline K220 & K219 & 0 & 0 & 0 & $\ldots$ & 0 & 0,045 \\
\hline
\end{tabular}

4) Menentukan nilai fungsi preferensi kuat $S P j$ menggunakan persamaan (7) yang membandingkan antar alternatif untuk setiap alternatif yang ada. Lalu menghitung nilai Strict Preference (SP) menggunakan persamaan (8) dimana bobot kriteria berdasaran Tabel 1. Matriks nilai SP disajikan pada Tabel 6.

Tabel 6. Matriks Nilai Strict Preference (SP)

\begin{tabular}{lccccccc}
\hline \multirow{2}{*}{ Alternatif } & \multicolumn{7}{c}{ Kriteria } \\
\cline { 3 - 8 } K1 & K2 & 0 & 0 & 0 & $\ldots$ & 0 & 0,258 \\
\hline K1 & K3 & 0 & 0 & 0 & $\ldots$ & 0 & 0,06 \\
\hline K1 & K4 & 0 & 0 & 0 & $\ldots$ & 0,012 & 0,336 \\
\hline$:$ & $:$ & $:$ & $:$ & $:$ & $:$ & $:$ & $:$ \\
\hline K220 & K219 & 0 & 0 & 0 & $\ldots$ & 0 & 0,045 \\
\hline
\end{tabular}

5) Menghitung nilai Total Preference (TP) menggunakan persamaan (9). Matriks nilai TP disajikan pada Tabel 7.

Tabel 7. Matriks Nilai Total Preference (TP)

\begin{tabular}{lccc}
\multicolumn{1}{c}{ Alternatif } & WP & SP & TP \\
\hline $\mathrm{TP}(1,2)$ & 0,2583 & 0,2583 & 0,5167 \\
\hline $\mathrm{TP}(1,3)$ & 0,06 & 0,06 & 0,1201 \\
\hline $\mathrm{TP}(1,4)$ & 0,3357 & 0,3357 & 0,6714 \\
\hline $\mathrm{TP}(1,5)$ & 0,3242 & 0,3242 & 0,6485 \\
\hline$:$ & $:$ & $:$ & $:$ \\
\hline $\operatorname{TP}(220,219)$ & 0,0452 & 0,0452 & 0,0905 \\
\hline
\end{tabular}


6) Menghitung nilai Leaving Flow, Entering Flow dan Net flow menggunakan persamaan (10), (11) dan (12) sehingga diperoleh hasil yang disajikan pada Tabel 8.

7) Menentukan prioritas alternatif didasarkan pada nilai net flow untuk semua alternatif yang diurutkan dalam urutan menurun. Nilai net flow tertinggi adalah alternatif prioritas terbaik. Urutan alternatif ditunjukkan pada Tabel 9.

Tabel 8. Nilai Leaving, Entering dan Net flow

\begin{tabular}{lccc}
\hline \multicolumn{1}{c}{ Alternatif } & Leaving & Entering & Net flow \\
\hline Keluarga 1 & 0,3909 & 0,1991 & 0,192 \\
\hline Keluarga 2 & 0,0788 & 0,3505 & $-0,272$ \\
\hline Keluarga 3 & 0,3507 & 0,2746 & 0,076 \\
\hline$:$ & $:$ & $:$ & \\
\hline Keluarga 220 & 0,2285 & 0,2625 & $-0,034$ \\
\hline
\end{tabular}

Tabel 9. Urutan Prioritas Tingkat Kesejahteraan Keluarga

\begin{tabular}{lcc}
\multicolumn{1}{c}{ Alternatif } & Net flow & Peringkat \\
\hline Keluarga 128 & 0,911 & 1 \\
\hline Keluarga 138 & 0,905 & 2 \\
\hline Keluarga 25 & 0,894 & 3 \\
\hline Keluarga 121 & 0,891 & 4 \\
\hline$:$ & $:$ & $:$ \\
\hline Keluarga 200 & $-0,050$ & 220 \\
\hline
\end{tabular}

Berdasarkan peringkat yang dihasilkan oleh metode EXPROM II yaitu urutan prioritas tingkat kesejahteraan keluarga dimana peringkat menggambarkan urutan keluarga tidak sejahtera hingga keluarga sejahtera. Data yang digunakan sebanyak 220 keluarga yang teriri atas 21 keluarga tidak sejahtera dan 199 keluarga sejahtera. Idealnya, keluarga tidak sejahtera berada pada urutan 1-21.

Untuk menganalisis hasil keputusan dari metode EXPROM II menggunakan bobot entropy digunakan confusion matrix yang disajikan pada Tabel 10 .

\begin{tabular}{clcc} 
Tabel 10. & \multicolumn{3}{c}{ Tabel Confusion Matrix dengan Bobot Entropy } \\
\hline & & \multicolumn{2}{c}{ DATA SUSENAS } \\
& & Tidak Sejahtera & Sejahtera \\
\hline \multirow{2}{*}{ EXPROM II } & 18 & 3 \\
& Tidak sejahtera & 3 & 196 \\
\cline { 2 - 3 } & Sejahtera & & \\
\hline
\end{tabular}

Dari Tabel 10 diperoleh tingkat akurasi berdasarkan bobot kriteria Entropy menggunakan persamaan (13) sebesar $97,27 \%$.

\section{B. Implementasi Aplikasi}

Sistem yang dibangun memiliki 2 level pengguna yaitu administrator dan operator. Administrator memiliki hak akses penuh terhadap keseluruhan fungsi pengelolaan sistem sedangkan untuk operator dapat melihat data-data berupa data alternatif, kriteria, subkriteria dan hasil urutas prioritas tanpa memiliki hak untuk mengubah data yang ada di sistem. Setiap user diharuskan melalukan proses login untuk dapat melihat isi dari sistem. Pada Gambar 1 ditampilkan halaman awal setelah melakukan proses login. 


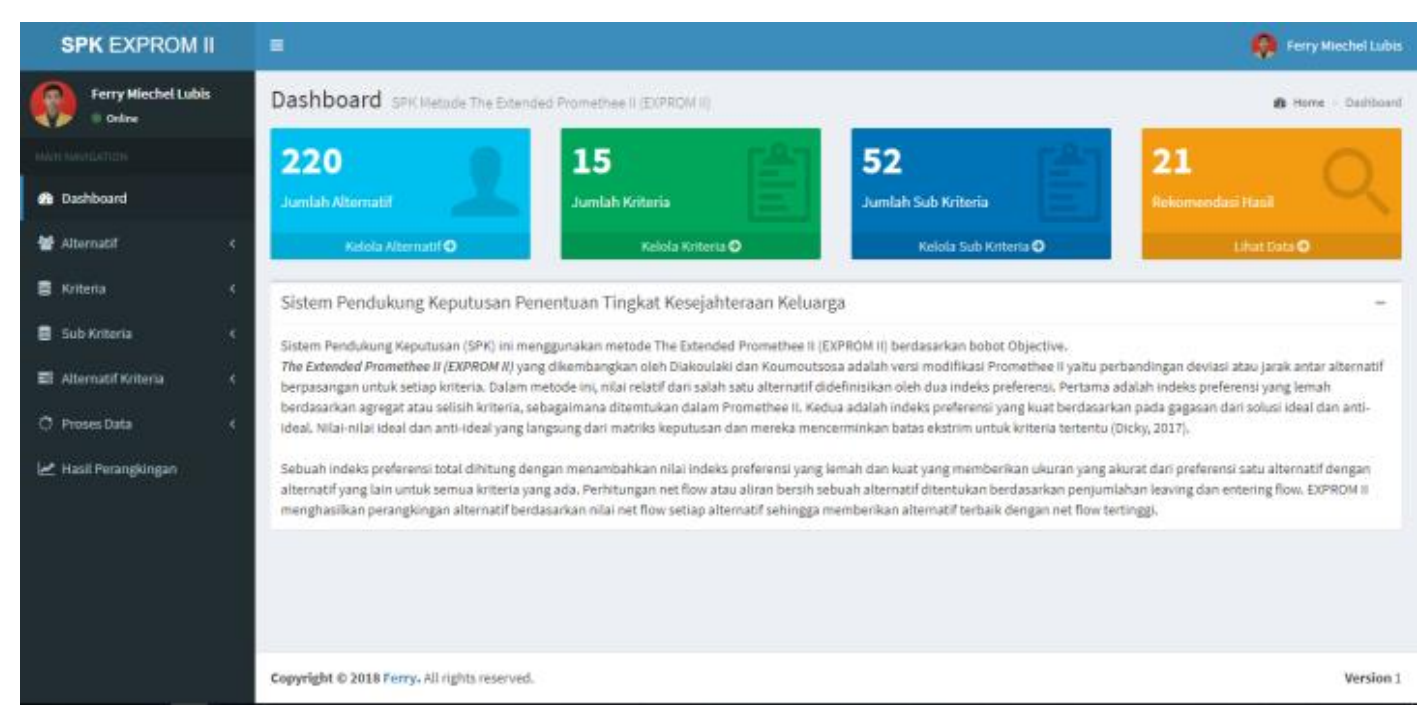

Gambar 1. Halaman Awal Aplikasi

Selanjutnya pada Gambar 2 terdapat data alternatif dimana kriteria-kriteria alternatif telah dikonversi oleh sistem ke dalam bobot subkriteria untuk setiap kriteria. Setiap alternatif memiliki nilai sesuai data set yang yang dikelola oleh administrator. Data yang perlu diisi yaitu nama alternatif, nama kriteria dan nilai datanya.

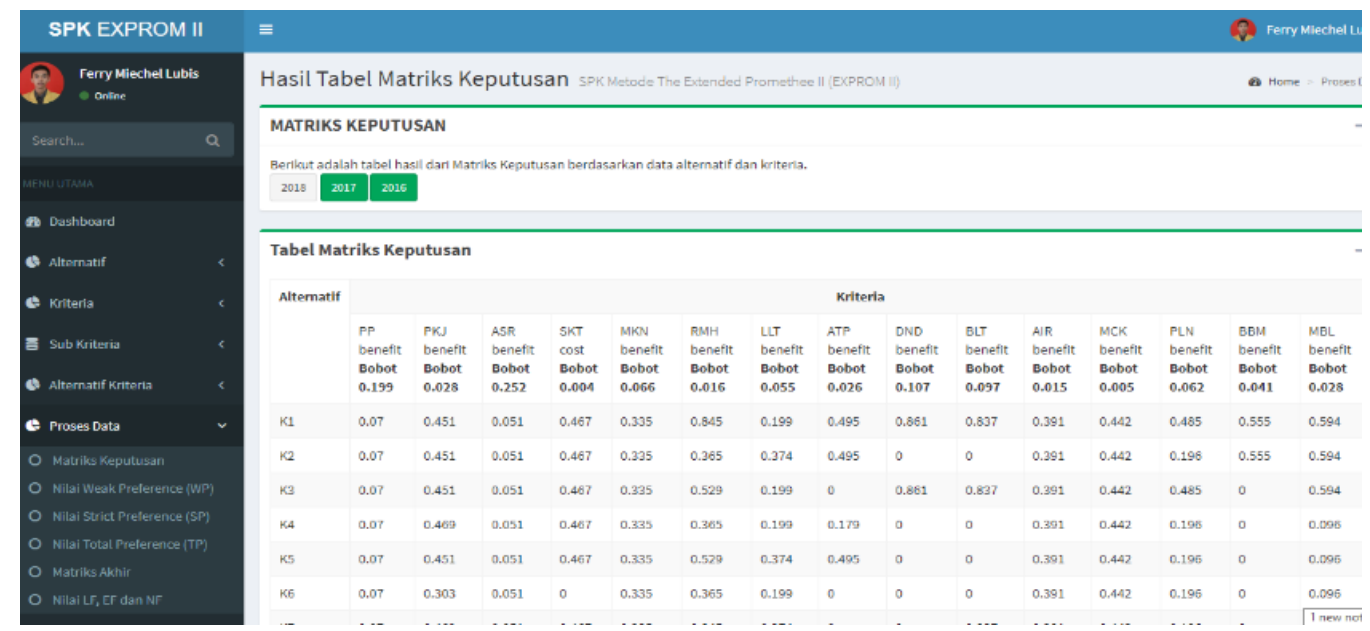

Gambar 2. Tampilan Data Alternatif Kriteria

\begin{tabular}{|c|c|c|c|}
\hline \multicolumn{3}{|c|}{ HASIL PERANGKINGAN } & - \\
\hline \multicolumn{4}{|c|}{ Berikut adalah tabel hasil perangkingan dari perhitungan oleh sistem. } \\
\hline \multicolumn{3}{|c|}{ HASIL PERANGKINGAN KELUARGA SEJAHTERA } & - \\
\hline Ranking & Alternatif & Nilai & \\
\hline 1 & K9 & 0.56 & \\
\hline 2 & K1 & 0.51 & \\
\hline 3 & K10 & 0.34 & \\
\hline 4 & K3 & 0.06 & \\
\hline 5 & K2 & 0.06 & \\
\hline 6 & K7 & -0.08 & \\
\hline 7 & k5 & -0.14 & \\
\hline 8 & K4 & -0.43 & \\
\hline 9 & K6 & -0.43 & \\
\hline 10 & к8 & -0.44 & \\
\hline
\end{tabular}

Gambar 3. Tampilan Hasil Urutan Prioritas Alternatif 
Setelah dilakukan proses perhitungan maka tampil hasil urutan berdasarkan nilai net flow tertinggi. Nilai net flow tertinggi akan berada di peringkat teratas yang menggambarkan alternatif dengan nilai net flow tertinggi merupakan alternatif terbaik untuk direkomendasikan sebagai penerima bantuan.

\section{Kesimpulan dan saran}

Hasil penelitian menunjukkan bahwa metode EXPROM II dapat diimplementasikan dalam sistem pendukung keputusan penentuan tingkat kesejahteraan keluarga yang menghasilkan urutan prioritas. Aplikasi yang dibuat dapat digunakan sebagai alat bantu atau rujukan dan bahan pertimbangan dalam mengambil keputusan, serta dengan aplikasi ini dapat memudahkan pihak pemerintah daerah dalam pemberian program bantuan guna pengentasan kemiskinkan agar tepat sasaran.

\section{Ucapan Terima Kasih}

Penulis mengucapkan terima kasih kepada Badan Pusat Statistik Provinsi Kalimantan Timur yang telah membantu dan memberi dukungan data terhadap penelitian ini.

\section{Daftar Pustaka}

[1] M. Wati and B. Cahyono, "Aplikasi Multi-Criteria Decision Making Penentuan Penerima Bantuan Sosial Santunan Warga Tidak Mampu Menggunakan PROMETHEE,” J. Rekayasa Teknol. Inf., vol. 2, no. 2, pp. 208-217, 2018.

[2] E. Budiman, N. Dengen, Haviluddin, and W. Indrawan, "Integrated multi criteria decision making for a destitute problem," Proceeding - 2017 3rd Int. Conf. Sci. Inf. Technol. Theory Appl. IT Educ. Ind. Soc. Big Data Era, ICSITech 2017, vol. 2018-Janua, pp. 342-347, 2018.

[3] A. Kurniawan and Rianto, "Implementasi Sistem Pendukung Keputusan Penentuan Warga Miskin Menggunakan Metode Simple Additive Weighting (SAW) Seri Sains dan Teknologi E-ISSN 26154765," J. Siliwangi Seri Sains dan Teknol., vol. 4, no. 2, pp. 72-77, 2018.

[4] B. P. S. Samarinda, Kota Samarinda Dalam Angka 2018. Samarinda: BPS Kota Samarinda, 2018.

[5] D. A. Ramdhan, D. Setyadi, and A. Wijaya, "Faktor-faktor yang mempengaruhi tingkat pengangguran dan kemiskinan di kota samarinda," Inovasi, vol. 13, no. 1, p. 1, 2018.

[6] M. Wati, "Analisis Metode Weighted Product dan Promethee Dalam Pemilihan Penerima Santunan Warga Tidak Mampu," J. Rekayasa Teknol. Inf., vol. 3, no. 1, pp. 96-105, 2019.

[7] S. Sarwosri, D. Sunaryono, R. J. Akbar, and R. D. Setiyawan, "Poverty Classification Using Analytic Hierarchy Process and K-Means Clustering," in International Conference on Information, Communication Technology and System (ICTS), 2016, pp. 266-269.

[8] A. Rusnawati, M. Wati, and H. J. Setyadi, "Sistem Pendukung Keputusan Penentuan Penerima Bantuan Sosial Daerah Kutai Kartanegara Menggunakan Metode TOPSIS,” JURTI, vol. 1, no. 2, pp. 160-169, 2017.

[9] M. A. Saputera, A. Tejawati, and M. Wati, "Sistem Pendukung Keputusan Penentuan Penerima Bantuan Daerah Menggunakan Weighted Product," Pros. Semin. Ilmu Komput. dan Teknol. Inf., vol. 2, no. 1, pp. 76-80, 2017.

[10] A. Rambe, Alokasi Pengeluaran Rumah Tangga dan Tingkat Kesejahteraan. Medan: Universitas Sumatera Utara, 2011.

[11] B. P. S. BPS, Indikator Kesejahteraan Rakyat 2018. 2018.

[12] E. Budiman and N. Dengan, "Performance of Decision Tree C4.5 Algorithm in Student Academic Evaluation," Lect. Notes Electr. Eng., vol. 488, pp. 380-389, 2018.

[13] K. D. Maisari, D. Andreswari, and R. Efendi, "Pembobotan Entropy Untuk Penentuan Calon Penerima Bantuan Siswa Miskin (BSM) APBD Kota Bengkulu ( Studi Kasus : SMAN 8 Kota Bengkulu ),” vol. 5, no. 2, 2017.

[14] M. Wati, N. Novirasari, and H. S. Pakpahan, "Evaluation of scholarly performance student using multicriteria decision-making with objective weight," Int. Electron. Symp. Knowl. Creat. Intell. Comput. IESKCIC 2018 - Proc., pp. 56-61, 2019.

[15] M. Wati, N. Novirasari, E. Budiman, and Haeruddin, "Multi-Criteria Decision-Making for Evaluation of Student Academic Performance Based on Objective Weights," in the Third International Conference on Informatics and Computer, 2019, no. 11, pp. 1-5.

[16] D. M. B. Tarigan, D. Palupi Rini, and Sukemi, "Particle Swarm Optimization - Based on Decision Tree of C4.5 Algorithm for Upper Respiratory Tract Infections (URTI) Prediction," J. Phys. Conf. Ser., vol. 1196, no. 1, 2019.

[17] Y. Gong, Y. Yu, K. Huang, J. Hu, and C. Li, "Evaluation of lithium-ion batteries through the simultaneous consideration of environmental, economic and electrochemical performance indicators," J. Clean. Prod., vol. 170, pp. 915-923, 2018. 
[18] N. Dicky, Multi Criteria Decision Making (MCDM) pada Sistem Pendukung Keputusan. Yogyakarta: Deepublish, 2017.

[19] L. T. Sianturi, A. Karim, A. Putera, and U. Siahaan, "Best Student Selection Using Extended Promethee II Method," Int. J. Recent Trends Eng. Res., vol. 3, no. 8, pp. 21-29, 2017.

[20] K. Palczewski and W. Sałabun, "Influence of various various normalization normalization methods methods in in PROMETHEE PROMETHEE II: an empirical study on the selection of the airport location an empirical study on the selection of the airport location," Procedia Comput. Sci., vol. 159, pp. 2051-2060, 2019.

[21] Y. Silalahi, M. Mesran, T. Zebua, and S. Suginam, "Penerapan the Extended Promethee II ( Exprom II) Untuk Penentuan Produk Diskon," KOMIK (Konferensi Nas. Teknol. Inf. dan Komputer), vol. I, no. 1, 2017.

[22] M. Wati, H. S. Pakpahan, and N. Novirasari, "Comparative Analysis of Multi-Criteria Decision Making for Student Degree Completion Time based on Entropy Weighted," Proc. ICAITI 2018 - 1st Int. Conf. Appl. Inf. Technol. Innov. Towar. A New Paradig. Des. Assist. Technol. Smart Home Care, pp. 56-61, 2019.

[23] M. Wati, Haeruddin, and W. Indrawan, "Predicting degree-completion time with data mining," Proceeding - 2017 3rd Int. Conf. Sci. Inf. Technol. Theory Appl. IT Educ. Ind. Soc. Big Data Era, ICSITech 2017, vol. 2018-Janua, pp. 732-736, 2018.

[24] Z. Saringat, A. Mustapha, R. R. Saedudin, and N. A. Samsudin, "Comparative Analysis of Classification Algorithms for Chronic Kidney Disease Diagnosis,” Bull. Electr. Eng. Informatics, vol. 8, no. 4, pp. 1496-1501, 2019.

[25] S. Tabassum, M. B. B. G, and J. Majumdar, "Analysis and Prediction of Chronic Kidney Disease using Data Mining Techniques,” Int. J. Eng. Res. Comput. Sci. Eng., vol. 4, no. 9, pp. 25-32. 